DOI:

UDK 538.911

A. Dedoborez, associate professor, Mathematphysics@gmail.com

A. Kletskov, assistant, alex.k187@i.ua

V. Tsotsko, senior lecturer

Dniprovsky State Agrarian and Economic University, Dnipro

\title{
DETERMINATION OF OPTIMAL PARAMETERS TO RECEIPT THE SEMICONDUCTOR TAPES OF CdSe/ZnTe ON BASIS OF MATHEMATICAL MODEL
}

Worked out mathematical model of receipt the semiconductor tapes for comparison with experimental data got the method of molecular-radial epitaxation.

Keywords: time of evaporation; speed of besieging; vaporizer; lining.

Розроблена математична модель отримання напівпровідникових плівок для зіставлення з експериментальними даними отриманими методом молекулярно-променевої епітаксії.

Ключові слова: час випаровування; швидкість осадження; випарник; підкладка.

\section{Problem's Formulation}

High enough speed of besieging of semiconductor tapes puts the problem of determination of the most optimal parameters of evaporation and creation of mathematical model by means of which it is possible it would be to change parameters for different configurations of semiconductor pellicle structures.

\section{Analysis of recent research and publications}

Research of structure and properties of semiconductor tapes of connections of $\mathrm{A}_{2} \mathrm{~B}_{6}$ many works are sanctified to, including [1,2,3]. For creation of mathematical model of receipt of semiconductor tapes drawn on the results of research of authors $[1,4,5,6]$.

\section{Formulation of the study purpose}

The purpose of work is development of mathematical model for determination of optimal parameters of receipt of semiconductor tapes on the basis of comparison with experimental data got the method of evaporation in a vacuum, determination of pressure of gases in middle of the quasi-closed volume of a vacuum post, time and temperature of evaporation.

\section{Presenting main material}

There are many methods of besieging of thin-films. General requirements to the receipt of thin-films is evenness of thickness of tape, homogeneity of her structure, high adgesion with lining or other tapes. From all methods of receipt of thin-films the method of thermal evaporation most answers the declared terms in a vacuum with the indirect heating by a glower (capacitance-resistance heating).

Essence of method of the capacitance-resistance heating consists in placing of the evaporated material in a vaporizer, which is heated by a current until then while pressure of pair of material will exceed pressure in a vacuum system. Vaporizers make from materials with subzero flying (tungsten, molybdenum). Capacitance-resistance vaporizers depending on a construction are to the wire, band and tigel. Most widespread from them are tigel vaporizers. Tigel vaporizer is bath in what place the evaporated material. Mostly the crucible is made from a refractory metal and has a form to the cone.

In this research a device was used for the all-epitaxial increase of tapes of VCC-5M. (fig. 1). At thermal evaporation distance of $L$ between a vaporizer and lining folded from a $100 \mathrm{~mm}$ to $500 \mathrm{~mm}$ Radius of ring of vaporizer $-r=5 \mathrm{~mm}$ Vaporizer was cutting-in in tungsten wire ( $\propto$ wire is a $0,8 \mathrm{~mm}$ ) with quartz crucible, where halkogen was loaded. Mass of evaporant folded from $50 \mathrm{mg}$ to $200 \mathrm{mg}$. A lining area is covered by the layer of tape of $F$ is $3 \cdot 10^{-4} \mathrm{~m}^{2}$. Pressure of remaining gas of $P$ is a $10^{-1}$ pascal. A closeness of matter of tape is $\rho(\mathrm{CdSe})=5,81 \cdot 10^{3} \mathrm{~kg} / \mathrm{m}^{3}$, a closeness of matter of tape is $\rho(\mathrm{ZnTe})=6,34 \cdot 10^{3} \mathrm{~kg} / \mathrm{m}^{3}$. 


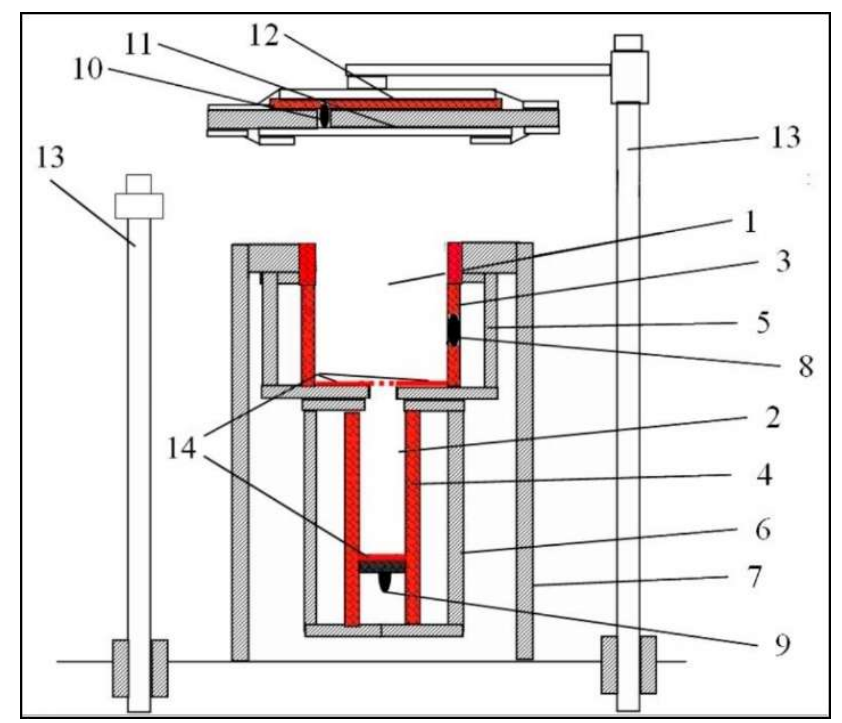

Fig. 1. Chart of device for the synthesis of tapes of CdSe and ZnTe in CCV: 1,2 are the evaporated compartments; 3,4 are heaters of walls; $5-7$ are afterheaters; $8-10$ are thermocouples; 11 is lining; 12 is a lining heater; 13 are stands; 14 are heater elements of vaporizer [1]

Properties of thin-films substantially depend on the parameters of process of besieging: speeds of besieging, temperature of lining, remaining vacuum and others like that

Speed of besieging is determined after a formula:

$$
v_{n}=\beta x q^{-1} R^{-2} v_{v}
$$

where $\beta$ is a coefficient of condensation, which takes into account the terms of condensation (frequency surfaces, temperature), $x$ - const, that depended on the form of vaporizer.

Speed of evaporation $v_{v}$ in id est amount of matter [2,3], evaporated for one second from unit of area of surface of vaporizer, calculates in obedience to the formula of Hertz-Knudsen [4] but looks like:

$$
v_{v}=0,585 P_{s} \sqrt{\frac{m}{T}}
$$

where $P_{s}$ is pressure of pair of matter.

In times of $t$ evaporation an amount of the evaporated matter is from the vaporizer of radius of $r$ :

$$
\sigma=\mathrm{w} \pi \mathrm{r}^{2} \mathrm{t} \text {. }
$$

On condition that all atoms of evaporant condense on lining a desorption is absent, it is possible to consider that $\sigma=G$, where $G$ is mass of the got tape.

The thickness of tape can be certain from correlation:

$$
d=\frac{v_{v} \pi r^{2} t}{F \rho}=\frac{0,585 \cdot P_{S} \sqrt{\frac{m}{T}}}{F \rho} \pi r^{2} t
$$

where $\mathrm{m}$ is mass of evaporant, $t$ is time of evaporation.

Thus under a thickness understand such thickness, which the layer of matter, equipartition for surfaces subspoon would have with the closeness of this matter. In an order to take into account the unevenness of distribution of tape for the surfaces of lining it is necessary to enter the coefficient of proportion of $Z$ :

$$
Z=\frac{1}{\left(1+\left(\frac{h}{L}\right)^{2}\right)^{3 / 2}}
$$

where $h$ is distance from the center of lining to the view point, $L$ is distance from a vaporizer to the center of lining.

Then finally will have a formula: 


$$
d=\frac{0,585 P_{s} \sqrt{\frac{m}{T}}}{F \rho\left(1+\left(\frac{h}{L}\right)^{2}\right)^{3 / 2}} \pi r^{2} t .
$$

Expression for high speed of evaporation (2) was got Lengmur [4] from experiments answers evaporation from free-form, id est situations of not "returning" of the evaporated particles are on the surface of lining. Such evaporation is named lengmured [4]. By a key variable which influences there is a temperature on speed, as she is strong influence on pressure saturated pair.

In this work for practical application it is approximately possible to apply a formula from the estimation of thermodynamics data $[4,5]$ for pressure saturated pair of matter $P_{s}$ above fusion evened:

$$
\ln P_{S}(m m . m . p)=-15.993 T^{-1}+12.409+0.999 \ln (T)-3.52 \cdot 10^{-2} T \text {. }
$$

At causing of tapes by the method of evaporation a matter must evaporate in the molecular mode (fig.1), an atomic (often as "molecular") bunch is here created, and his particles move from a vaporizer to the subspoon rectilineal, without collisions. In obedience to these terms and on the basis of kinetic theory of gases it is possible to get next dependence:

$$
L \approx 5 \cdot 10^{-3} / P_{S}(m m . m . p) \text {. }
$$

Then according to initial data will get a value $P$ snear $1-7$ Pascal. Putting finding to (7) will get the value of near $600-650 \mathrm{~K}$.

For determination of time of evaporation it is necessary to compare the experimental and theoretical values of thickness of tapes. The thickness of tape on a flat subspoon which is athwart to the normal to the surface of vaporizer is determined by expressions [6]:

$$
d=\frac{m L}{4 \pi \rho a^{3}}
$$

and

$$
d=\frac{m L^{2}}{\pi \rho a^{4}}
$$

where $a$ - is distance from a vaporizer to the looks point, $L$ is distance from a vaporizer to the center of lining.

For determination of thickness of $d$ in the set point of subspoon it is necessary look to examine evaporation from all elements of ring [6]. The angular co-ordinates of element of vaporizer are determined by a corner $\alpha$, and for the stowage of holding from every element it is necessary to integrate for $\alpha$ from 0 to $2 \pi$.

$$
a^{2}=L^{2}+r^{2}+h^{2}+2 h r \cos (\alpha),
$$

where $h$ is distance from the center of lining to the looks point, $r$ is a radius of ring of vaporizer.

At calculations assumptions are done in relation to descriptions of evaporation from the separate elements of vaporizer. HollandandShtekelmaher conducted a calculation for a "ring which consists of point or superficial vaporizers". Integration for $\alpha$ equalizations (9) and (10) taking into account equality (11) gives for a size $d$ expression:

$$
d=\frac{m}{\pi \cdot \rho} \frac{L^{2}\left(L^{2}+h^{2}+r^{2}\right)}{\left(\left(L^{2}+h^{2}+r^{2}\right)^{2}-4 r^{2} h^{2}\right)^{3 / 2}} .
$$

Comparing expressions (12) and (6) can get expression for time of condensate $t$ :

$$
t=\frac{m}{\pi \rho} \frac{L^{2}\left(L^{2}+h^{2}+r^{2}\right)}{\left(\left(L^{2}+h^{2}+r^{2}\right)^{2}-4 r^{2} h^{2}\right)^{3 / 2}} \cdot \frac{F \rho\left(1+\left(\frac{h}{L}\right)^{2}\right)^{3 / 2}}{0,585 P_{S} \sqrt{\frac{m}{T}} \pi r^{2}} .
$$

Time of evaporation folds from $5 \mathrm{c}$ to a few minutes, depending on mass of condensate matter.

Coming from finding can define the optimal parameters of receipt of semiconductor tapes. Pressure of pair of matter $P_{S}$ it is better to do a permanent size (in this research 5 pascal), id est distance from $a$ vaporizer to lining always unchanging. Also from these data swims out, that and a temperature of evaporation is a permanent size.

Knowing what thickness of semiconductor tape it is necessary condensate on lining it is possible from a formula (12) to expect mass of evaporant. Time of evaporation of $t$ settles accounts after a formula (13) for every found mass of evaporant. 


\section{Conclusions}

The worked out mathematical model provides high enough exactness of approximation and flexibility to the change of terms of receipt.

For the brought objects over it is got: pressure steam evaporant -5 Pascal optimal temperature of evaporation - $650 \mathrm{~K}$, optimal value of distance from a vaporizer to lining - a $100 \mathrm{~mm}$ a mathematical model is created for the calculation of thickness of semiconductor tape and time to the necessity for her causing on lining. Research of receipt of tapes of different thickness is conducted, at it data of experiment with high exactness of near with data of theory.

\section{References}

[1] Opanasiuk, A.S. (2011). Strukturni, elektrophizichni ta optichni vlastivosti plivok spoluk A2B6 ta heteroperekhodiv na ikh osnovi [Structural, electro-physical and optical properties of tapes of connections of A2B6 and hetero transitions are on their basis]. Doctor's thesis. Sumy: SumDU [in Ukrainian].

[2] Shyju, T.S., \& Anandhi, S., \& Indirajith R. (2011). Solvothermal synthesis deposition and characterization of cadmium selenide (CdSe) thin films by thermal evaporation technique. Journal Crystal Growth. Netherlands, Volume. 337, P. 38-45. [in English].

[3] Pathel, K.D.,\& R.K., Shan, \& D.L. Makhija Chemical and structural characterization of CdSe thin films. Journal Ovonic Research. Romania, V.4, № 61,P.129-139. [in English].

[4] Maisell, L., Gleng, R. (1977). Tekhnolohiia tonkikh plienok: spravochnik [Technology of thinfilms : reference book] (Vols.1). Moskva: Soveight radio. [in Russian].

[5] Nesmeianov, A.N. (1961). Davlenie para khimicheskikh elementov [Pressure of steam of chemical elements]. Moskva: AN USSR [in Russian].

[6] Hass., G., \& R.E., Thun (1986). Phisics of thin films. Academic Press. New York, Volume. 3, P. 38-44.

\section{ВИЗНАЧЕННЯ ОПТИМАЛЬНИХ ПАРАМЕТРІВ ОТРИМАННЯ НАПІВПРОВІДНИКОВИХ ПЛІВОК CdSe/ZnTe НА ОСНОВІ МАТЕМАТИЧНОЇ МОДЕЛІ Дідоборець О.Й., Клєцков О.М., Цоцко В.І.}

\section{Реферат}

Метою роботи $є$ розробка математичної моделі для визначення оптимальних параметрів отримання напівпровідникових плівок на основі зіставлення 3 експериментальними даними отриманими методом випаровування у вакуумі, визначення тиску газів усередині квазізамкнутого об'єму вакуумного посту, часу та температури випаровування

Існує багато методів осадження тонких плівок. Загальними вимогами до отримання тонких плівок $є$ рівномірність товщини плівки, однорідність ії структури, висока адгезія з підшарком або іншими плівками. 3 усіх методів отримання тонких плівок найбільш відповідає заявленим умовам метод термічного випаровування у вакуумі з непрямим підігрівом ниткою розжарення (резистивний підігрів).

Сутність методу резистивного підігріву полягає в розміщенні випарюваного матеріалу у випарник, який нагрівається струмом до тих пір доки тиск пари матеріалу перевищить тиск у вакуумній системі. Випарники виготовляють з матеріалів з низькою леткістю (вольфрам, молібден). Резистивні випарники в залежності від конструкції бувають дротові, стрічкові та тигельні. Найбільш поширеними 3 них $є$ тигельні випарники. Тигельним випарником $є$ ванна в яку поміщають випарюваний матеріал. Найчастіше тигель виготовляється 3 тугоплавкого металу та має форму конусу. 
В даному дослідженні використовувався пристрій для епітаксіального нарощування плівок ВУП-5М. (рис. 1). При термічному випарі відстань $L$ між випарником і підкладкою складала від 100 мм до 500 мм. Радіус кільця випарника $-r=5$ мм. Випарник був вставленим у вольфрамову проволоку (ฉ проволоки 0,8 мм) з кварцевим тиглем, куди завантажувався халькоген. Маса випаровуваної речовини складала від 50 мг до 200 мг. Площа підкладки покрита шаром плівки $F=3 \cdot 10^{-4} \mathrm{~m}^{2}$. Тиск залишкового газу $P=10^{-1}$ Па. Щільність речовини плівки $-\rho(\mathrm{CdSe})=$ $5,81 \cdot 10^{3} \mathrm{\kappa г} / \mathrm{M}^{3}$, щільність речовини плівки $-\rho(\mathrm{ZnTe})=6,34 \cdot 10^{3} \mathrm{\kappa г} / \mathrm{m}^{3}$

Розроблена математична модель забезпечує досить високу точність апроксимації та гнучкість до зміни умов отримання.

Для приведених об'єктів отримано: тиск парів випаровуваної речовини -5 Па, оптимальний температура випаровування - 650 К, оптимальне значення відстані від випарника до підкладки - 100 мм. Створена математична модель для розрахунку товщини напівпровідникової плівки та часу необхідному для іiї нанесення на підкладку. Проведено дослідження отримання плівок різних товщин, при цьому дані експерименту з високою точністю співпадають 3 даними теорії.

\section{Література}

1. Опанасюк А.С. Структурні, електрофізичні та оптичні властивості плівок сполук $\mathrm{A}_{2} \mathrm{~B}_{6}$ та гетеропереходів на їх основі: дис. докт. фіз.-мат. наук: 01.04.01 / Сумський державний університет. Суми, 2011. 378 с.

2. Shyju T.S., Anandhi S., Indirajith R. Solvothermal synthesis deposition and characterization of cadmium selenide (CdSe) thin films by thermal evaporation technique. Journal Crystal Growth. Netherlands, 2011. Volume. 337. P. 38-45.

3. Pathel K.D., R.K. Shan, D.L. Makhija Chemical and structural characterization of CdSe thin films. Journal Ovonic Research.Romania. 2008. V.4, № 61. P. 129-139.

4. Технология тонких пленок : справочник / Под ред. Л. Майселла, Р. Глэнга. Москва.: Сов. радио, 1977. Т.1. $662 \mathrm{c.}$

5. Несмеянов А.Н. Давление пара химических элементов. Москва: Издательство АН СССР, $1961.396 \mathrm{c}$.

6. Hass.G., R.E. Thun Phisics of thin films. Academic Press. New York, 1986. Volume. 3 P. 38-44. 